\title{
MENEJEMEN SARANA PRASARANA DALAM MENINGKATKAN MUTU LULUSAN DI MTS NEGERI TRIWARNO KUTOWINANGUN KEBUMEN
}

\author{
Ahmad Safingudin \\ (MTs Negeri 8 Kebumen) \\ ah_safi@yahoo.co.id
}

\begin{abstract}
ABSTRAK
Sarana prasarana merupakan faktor penting dalam meningkatkan mutu lulusan, Madrasah Tsanawiyah Negeri Triwarno Kutowinangun Kebumen dalam dua tahun terakhir ini sangat konsen terhadap pemenuhan sarana dan prasarana, penelitian ini bertujuan untuk: (1) Mengkaji dan membahas Perencanaan Menejemen Sarana dan Prasarana Pendidikan dalam Meningkatkan Mutu Lulusan di MTs Negeri Triwarno Kutowinangun Kebumen, (2) Menganalisi Pengorganisasian Manajemen Sarana dan Prasarana Pendidikan dalam Meningkatkan Mutu Lulusan di MTs Negeri Triwarno Kutowinangun Kebumen. (3). Menganalisis dan Membahas Pengarahan Manajemen Sarana dan Prasarana Pendidikan dalam Meningkatkan Mutu Lulusan di MTs Negeri Triwarno Kutowinangun Kebumen. (4). Menganalisis Pengendalian Manajemen Sarana dan Prasarana Pendidikan dalam Meningkatkan Mutu Lulusan di MTs Negeri Triwarno Kutowinangun Kebumen.

Penelitian ini menggunakan metode kualitatif. Penelitian dilakukan di MTs Negeri Triwarno Kutowinangun Kebumen, pada bulan Mei sampai Oktober 2017. Subjek dalam penelitian ini adalah Kepala Madrasah dan Waka Sarana Prasarana MTs Negeri Triwarno Kutowinangun Kebumen. Adapun informan dalam penelitian adalah Guru dan Siswa. Teknik pengumpulan data dengan cara wawancara, observasi dan dokumentasi. Teknik keabsahan data menggunakan Triangulasi data dan Triangulasi sumber. Teknik analisis data menggunakan metode interaktif, pengumpulan data, penyajian data, reduksi data dan penarikan kesimpulan.

Hasil penelitian diketahui bahwa Menejemen sarana dan prasarana dalam peningkatan mutu lulusan di MTs Negeri Triwarno Kutowinangun Kebumen dilakukan dengan (1) Perencanaan Sarana dan Prasarana (Planing), yaitu rapat koordinasi madrasah,

penetapan program madrasah, serta penetapan kebutuhan sarana dan prasarana pendidikan. (2) Pengorganisasian Sarana dan Prasarana (Organizing) meliputi pengaturan struktur organisasi pengelola sarana dan prasarana, pembagian tugas kerja/job deskripsi, pengaturan alat dan bahan praktek, serta pengaturan kegiatan praktek. (3) Pengarahan Sarana dan Prasarana (Actuating) berupa pengadaan, pemeliharaan dan penghapusan sarana dan prasarana. (4) Pengontrolan Sarana dan Prasarana (Controling) dilakukan dengan inventarisasi. Penggunaan sarana dan prasarana hendaknya disesuaikan dengan kebutuhan agar diperoleh manfaat dari penggunaan tersebut. Seluruh warga madrasah hendaknya memanfaatkan sarana dan prasarana yang dimiliki madrasah agar tidak terbuang percuma hanya menjadi hiasan saja karena pada dasarnya semua fasilitas madrasah diadakan untuk memberikan layanan yang terbaik kepada semua warga madrasah. Pemeliharaan sarana dan prasarana madrasah tidak hanya diserahkan pada petugas yang menanganinya saja tetapi sumbangsih atau proaktif semua warga madrasah juga diperlukan agar semua program yang direncanakan dalam pemeliharaan madrasah dapat terealisasikan dengan baik demi kelangsungan proses pendidikan di madrasah.
\end{abstract}

Kata kunci: Manajemen, Sarana Prasarana, Mutu Lulusan 


\section{PENDAHULUAN}

Pendidikan merupakan arahan bagi manusia agar tumbuh sesuai dengan apa yang ada padadiri dan lingkungannya untuk menjadi jati diri yang hakiki. Upaya yang dapat dilakukan untuk mewujudkan hal tersebut, penyelenggaraan pendidikan harus sesuai dengan Undang-undang (UU) dan Peraturan Pemerintah (PP) mengenai Sistem Pendidikan Nasional. Ditegaskan dalam pasal 4 ayat 1 Undang-Undang Nomor 20 Tahun 2003 tentang Sistem Pendidikan Nasional bahwa pendidikan diselenggarakan secara demokratis dan berkeadilan serta tidak diskriminatif dengan menjunjung tinggi hak asasi manusia, nilai keagamaan, nilai kultural, dan kemajemukan bangsa. ${ }^{1}$

Pendidikan dipengaruhi oleh lingkungan dan diselenggarakan berdasarkan perkembangan dan potensi yang ada pada peserta didik. Potensi peserta didik harus dibina secara berjenjang dan berkelanjutan seperti yang dijelaskan pada BAB VI Undang-Undang Nomor 20 Tahun 2003 bahwa jalur pendidikan terbagi atas pendidikan formal, non formal, dan informal yang dapat saling melengkapi dan memperkaya. Jalur pendidikan formal terdiri atas pendidikan dasar, pendidikan menengah, dan pendidikan tinggi. Pendidikan dasar sendiri berbentuk Sekolah Dasar (SD) dan Madrasah Ibtidaiyah (MI) atau bentuk lain yang sederajat, serta Sekolah Menengah Pertama (SMP) dan Madrasah Tsanawiyah (MTs) atau bentuk lain yang sederajat.

Pendidikan memiliki standar yang digunakan sebagai acuan dan kriteria minimal untuk peningkatan mutunya. BAB IX Undang-Undang Nomor 20 Tahun 2003 menjelaskan Standar Nasional Pendidikan terdiri atas standar isi, proses, kompetensi lulusan, tenaga kependidikan, sarana dan prasarana, pengelolaan, pembiayaan, dan penilaian pendidikan yang harus ditingkatkan secara berencana dan berkala.

Bersumber pada Undang-Undang Nomor 20 Tahun 2003 kemudian muncul Peraturan Pemerintah Republik Indonesia Nomor 19 Tahun 2005 tentang Standar Nasional Pendidikan yang selanjutnya dilakukan perubahan pada Peraturan Pemerintah Republik Indonesia Nomor 32 Tahun 2013 disebutkan lingkup standar nasional pendidikan meliputi standar isi, standar proses, standar kompetensi lulusan, standar sarana dan prasarana, standar pengelolaan, standar pembiayaan, dan standar penilaian pendidikan. Salah satu standar tersebut adalah standar sarana dan prasarana yang diatur lebih lanjut dalam Peraturan Menteri Pendidikan Nasional Republik Indonesia Nomor 24 Tahun 2007 tentang standar sarana dan prasarana sebagai upaya yang berkelanjutan dalam pemenuhan standar

\footnotetext{
${ }^{1}$ Undang-undang Nomor 20 Tahun 2003 tentang Sistem Pendidikan Nasional.
} 
sarana dan prasarana pendidikan untuk Sekolah Dasar/ Madrasah Ibtidaiyah (SD/ MI), Sekolah Menengah Pertama/ Madrasah Tsanawiyah (SMP/ MTs), dan Sekolah Menengah Atas/ Madrasah Aliyah (SMA/ MA). Peraturan menteri tersebut menjelaskan kriteria minimal sarana dan prasarana yang dimiliki oleh sekolah.

Sarana pendidikan adalah semua perangkat peralatan, bahan, dan perabot yang secara langsung digunakan dalam proses pendidikan di sekolah. ${ }^{2}$ Berkaitan dengan ini, pengertian prasarana pendidikan adalah semua perangkat kelengkapan dasar yang secara tidak langsung menunjang pelaksanaan proses pembelajaran di sekolah. Penekanan pada pengertian tersebut adalah pada sifatnya, sarana bersifat langsung dan prasarana tidak bersifat langsung dalam menunjang proses pendidikan.

Sarana dan prasarana pendidikan perlu manajemen yang baik untuk menunjang kegiatan belajar mengajar sesuai Husaini Usman menguraikan definisi manajemen dalam arti luas adalah perencanaan, pelaksanaan, dan pengawasan (P3) sumber daya organisasi untuk mencapai tujuan secara efektif dan efisien. Manajemen dalam arti sempit adalah manajemen sekolah/ madrasah, pengawas/ evaluasi, dan sistem informasi sekolah/ madrasah. $^{3}$

Manajemen sekolah atau lembaga pendidikan termasuk dalam lingkup manajemen pendidikan. Manajemen sarana dan prasarana diharapkan dapat membantu sekolah dalam merencanakan kebutuhan fasilitas, mengelola pengadaan fasilitas, mengelola pemeliharaan fasilitas, mengelola kegiatan inventaris sarana dan prasarana, serta mengelola kegiatan penghapusan barang inventaris sekolah. ${ }^{4}$

Sekolah yang kurang pemeliharaannya kadang-kadang kelihatan kumuh, hal ini akan berpengaruh pada proses belajar-mengajar. Sebaiknya sekolah yang benar-benar memenuhi syarat keberhasilan, keindahan, kesehatan, ketertiban dan keamanan akan mempunyai pengaruh positif terhadap proses pendidikan dan keadaan itu sendiri akan memberikan pengaruh yang positif kepada para siswa. Berbagai upaya telah banyak dilakukan oleh pemerintah dan masyarakat untuk mewujudkan tujuan pendidikan nasional, seperti : pemantapan pelaksanaan kurikulum, peningkatan jumlah, jenis dan kualitas tenaga kependidikan, peningkatan jumlah, jenis dan kualitas sarana dan prasarana pendidikan. Agar semua upaya peningkatan kualitas pendidikan dapat tercapai maka kegiatan-kegiatan

\footnotetext{
${ }^{2}$ Arifin \& Barnawi. Etika dan Profesi Kependidikan. (Jogjakarta: Ar-Ruzz Media, 2012), hlm.47.

${ }^{3}$ Husaini Usman. Manajemen: Teori, Praktik, dan Riset Pendidikan. (Jakarta: Bumi Aksara, 2013), hlm.6.

${ }^{4}$ Permendiknas RI Nomor 13 Tahun 2007 tentang Manajemen Sarana dan Prasarana Pendidikan Persekolahan.
} 
menuju tercapainya tujuan tersebut perlu ditunjang oleh layanan manajemen/pengelolaan yang teratur dan memadai.

Demikian juga peningkatan jumlah, jenis, serta kualitas sarana dan prasarana pendidikan baik pendidikan dalam sekolah, maupun luar sekolah harus ditunjang oleh perangkatan pelayanan manajemen sarana dan prasarana yang tertib sehingga dapat mencapai tiga aspek kegunaan, yaitu hasil guna, tepat guna dan daya guna. Jika sarana dan prasarana pendidikan sudah memenuhi ketiga aspek kegunaan maka diharapkan kualitas pendidikan dapat diwujudkan sesuai dengan harapan. Gedung sekolah/madrasah yang mempunyai ruang-ruang belajar yang memenuhi syarat. Jelas lebih memberikan kemungkinan kepada siswa untuk belajar lebih enak dibandingkan dengan ruang belajar yang sempit, udara yang kurang lancar sirkulasinya dan cahaya yang kurang memenuhi syarat. Demikian juga tata ruang baca perpustakaan, ruang bimbingan dan penyuluhan dengan demikian jelas bahwa peralatan akan membantu dalam meningkatkan kualitas pendidikan sekolah/madrasah. Pengadaan alat-alat belajar selain gedung tidak kalah pelik dan mahal jika dibandingkan dengan pengadaan tempat belajar tersebut. Peralatan laboratorium ada yang harganya mahal sekali. Akan tetapi juga ada peralatan yang sangat murah sekali seperti papan tulis, kapur tulis, dan anehnya peralatan tersebut kurang diperhatikan dengan sungguh-sungguh. Hal yang kecil tersebut akan mempunyai pengaruh besar dalam proses belajar mengajar.

Guru merupakan faktor yang penting dalam meningkatkan kualitas pendidikan. Namun bukan berarti keberadaan unsur-unsur lain tidak begitu penting bagi peningkatan kualitas pendidikan di sekolah. Guru memerlukan adanya layanan yang profesional di bidang sarana dan prasarana dalam menerapkan kemampuan yang maksimal dengan demikian, di samping dibutuhkannya guru-guru yang memiliki kemampuan dan kecakapan yang lebih memadai, juga diperlukan cara-cara bekerja dan sikap yang baru, peralatan yang lengkap, dan sistem administrasi yang lebih teratur.

Keberhasilan program pendidikan melalui proses belajar mengajar sangat dipengaruhi oleh banyak faktor, salah satu di antaranya adalah tersedianya sarana dan prasarana pendidikan yang memadai disertai pemanfaatan dan pengelolaan secara optimal. Sarana dan prasarana pendidikan merupakan salah satu sumber daya yang penting dan utama dalam menunjang proses pembelajaran di sekolah, untuk itu perlu dilakukan peningkatan dalam pendayagunaan dan pengelolaannya agar tujuan yang diharapkan dapat tercapai. Dewasa ini masih sering ditemukan banyak sarana dan prasarana pendidikan yang dimiliki oleh sekolah yang diterima sebagai bantuan, baik dari pemerintah maupun masyarakat yang tidak 
optimal penggunaannya dan bahkan tidak dapat lagi digunakan sebagaimana fungsinya. Hal itu disebabkan antara lain oleh kurangnya kepedulian terhadap sarana dan prasarana yang dimiliki serta tidak adanya pengelolaan yang memadai. Seiring dengan perubahan pola pemerintahan setelah diberlakukannya otonomi daerah maka pola pendekatan manajemen sekolah/madrasah berubah, yakni lebih bernuansa daerah. Dengan adanya otonomi sekolah ini diharapkan sekolah dapat mengelola masing-masing sekolahnya dengan baik, terutama dalam manajemen sarana dan prasarananya.

Hal di atas menjadi salah satu faktor penghambat kualitas pendidikan di sekolah. Sebab para ahli pendidikan mengungkapkan bahwa pendidikan dikatakan berkualitas jika faktor pendukungnya juga berkualitas. Faktor-faktor tersebut adalah pendidik, peserta didik, tujuan pendidikan, alat-alat pendidikan dan lingkungan. Jadi cukup jelas bahwa alat (sarana dan prasarana) pendidikan merupakan faktor penting dalam tujuan pendidikan selain faktorfaktor lainnya. Karena dengan alat (sarana dan prasarana) pendidikan yang ter manage dengan baik maka dapat meningkatkan produktivitas pendidikan, sehingga pendidikan akan lebih dinamis, pengajaran lebih mantap dan penyajian lebih luas.

Sarana dan prasarana pendidikan merupakan salah satu faktor pendidikan yang keberadaannya sangat mutlak dalam proses pendidikan, hal ini menunjukkan bahwa sarana dan prasarana pendidikan tersebut tidak bisa dipisahkan dari faktor lainnya. Kegiatan belajar mengajar di kelas memerlukan sarana atau fasilitas yang sesuai dengan kegiatan yang harus dilakukan oleh guru dan murid.

Dengan adanya manajemen sarana dan prasarana pendidikan mampu mendayagunakan semua sarana dan prasarana pendidikan secara efektif dan efisien. Tujuan manajemen sarana dan prasarana secara umum adalah untuk memberikan layanan secara profesional dibidang sarana dan prasarana pendidikan dalam rangka terselenggarakannya pendidikan secara efektif dan efisien.

Inventarisasi sarana dan prasarana dilakukan dari awal karena seluruh sarana dan prasarana sudah diinventarisasi dengan baik, petugas pengelola sarana prasarana yaitu wakil kepala urusan bidang sarana prasarana (penanggung jawab sarana prasarana) berpengaruh proses inventarisasi dan pengelolaan yang lebih. Kondisi sarana dan prasarana MTs Negeri Triwarno Kebumen sesuai standar nasional, sehingga dalam kegiatan intra dan ekstra pembelajaran dapat berjalan maksimal. Misalnya saja ketersediaan perpustakaan yang baik untuk menempatkan buku buku dan ruang baca yang nyaman, ketersediaan lapangan olah raga sebagai sarana mengolah fisik, ketersediaan tempat ibadah yang besar bersih untuk mengolah rohani dan masih banyak sarana dan prasarana lain yang mumpuni dan memadai.. 
Dengan demikian pengelola sarana prasarana di MTs Negeri Triwarno Kuthowinangun Kebumen melakukan manajemen sarana dan prasarana dengan baik.

Dari uraian di atas penulis mengadakan penelitian ini dengan judul " Manajemen Sarana dan Prasarana Pendidikan Dalam Meningkatkan Mutu Lulusan Di MTs Negeri Triwarno Kutowinangun Kebumen Jawa Tengah".

Penelitian ini bertujuan untuk mengkaji dan membahas mengenai Perencanaan, Pengorganisasian, Pengarahan dan Pengendalian Manajemen Sarana dan Prasarana Pendidikan dalam Meningkatkan Mutu Lulusan di MTs Negeri Triwarno Kutowinangun Kebumen.

Hasil penelitian ini diharapkan dapat memberikan manfaat baik secara konsep maupun implementasi berdasarkan penelitian empiris. (1) Bagi Kementerian Agama Kabupaten Kebumen, penelitian ini diharapkan dapat dijadikan sebagai bahan pertimbangan bagi Kementerian Agama Kabupaten Kebumen untuk dapat melakukan pengelolaan, pengembangan dan peningkatan sarana prasarana pendidikan di MTs Negeri Triwarno Kutowinangun Kebumen dengan lebih baik. (2) Bagi Kepala Madrasah, penelitian ini diharapkan dapat dijadikan sebagai sumber acuan atau pedoman agar mampu mengelola dan memimpin Madrasahnya dengan lebih baik serta diharapkan sebagai pedoman agar mampu melaksanakan tugasnya secara maksimal dan mampu meningkatkan sarana prasarana pendidikan sehingga dapat meningkatkan kualitas madrasah yang dipimpinnya. (3) Bagi Guru, bagi Bapak dan Ibu Guru agar lebih memahami tentang sarana dan prasarana, sehingga suatu saat ada peluang menjadi Kepala Madrasah telah mempunya bekal untuk menjadi seorang pemimpin. (4) Pengawas Pendidikan, dengan memahami tentang peningkatan sarana dan prasarana pendidikan akan lebih mudah bagi pengawas dalam membina Madrasah menuju lembaga pendidikan yang lebih berkualitas.

\section{KAJIAN LITERATUR}

\section{Manajemen Sarana dan Prasarana Pendidikan}

Manajemen sarana dan prasarana diharapkan dapat membantu sekolah dalam merencanakan kebutuhan fasilitas, mengelola pengadaan fasilitas, mengelola pemeliharaan fasilitas, mengelola kegiatan inventaris sarana dan prasarana, serta mengelola kegiatan penghapusan barang inventaris sekolah/madrasah. ${ }^{5}$

${ }^{5}$ Ibid. 
a. Perencanaan (Planning) Sarana dan Prasarana Pendidikan

Kegiatan perencanaan sarana dan prasarana pendidikan sangat penting guna menghindari terjadinya kesalahan yang tidak diinginkan. Proses perencanaan harus dilakukan dengan cermat dan teliti baik berkaitan dengan karakteristik sarana dan prasarana yang dibutuhkan, jumlahnya, jenisnya, dan kendalanya (manfaat yang didapatkan), beserta harganya. Perencanaan yang matang sangat berpengaruh pada pelaksanaan kegiatan untuk mencapai tujuan yang telah ditetapkan.

Ibrahim Bafadal menjelaskana bahwa perencanaan sarana dan prasarana adalah suatu proses memikirkan dan menetapkan program pengadaan fasilitas sekolah, baik yang berbentuk sarana maupun prasarana pendidikan di masa yang akan datang untuk mencapai tujuan tertentu. ${ }^{6}$ Agar perencanaan dapat berjalan dengan baik, persyaratan perencanaan sarana dan prasarana pendidikan juga harus diperhatikan. Juliatriarsa menyebutkan lima syarat perencanaan yang baik, yaitu: (1) Berdasarkan pada alternatif. (2) Harus realistis. (3) Rencana harus ekonomis. (4) Rencana harus fleksibel. (5) Dilandasi partisipasi. $^{7}$

\section{b. Pengorganisasian (Orgenazing) Sarana dan Prasarana Pendidikan}

Pengadaan sarana dan prasarana merupakan kegiatan lanjutan dari perencanaan dalam manajemen sarana dan prasarana pendidikan. Pengadaan sarana dan prasarana merupakan fungsi operasional pertama dalam manajemen sarana dan prasarana pendidikan yang merupakan serangkaian kegiatan untuk menyediakan sarana dan prasarana pendidikan sesuai dengan kebutuhan.

\section{c. Pengarahan (Actuating) Sarana dan Prasarana Pendidikan}

Pengarahan sarana dan prasarana merupakan kegiatan yang berupa menjaga keberlangsungan fungsi sarana dan prasarana pendidikan agar dapat digunakan secara berulang. Pemeliharaan sarana dan prasarana pendidikan adalah kegiatan untuk melaksanakan pengurusan dan pengaturan agar semua sarana dan prasarana selalu dalam keadaan baik dan siap untuk digunakan secara berdayaguna dan berhasil guna dalam mencapai tujuan pendidikan.

\section{d. Pengawasan (Controlling) Sarana dan Prasarana Pendidikan}

Pengawasan adalah keseluruhan upaya untuk memelihara sarana prasarana, menginventarisasi sarana prasarana dan penghapusan sarana prasarana yang bertujuan

\footnotetext{
${ }^{6}$ Ibrahim Bafadal. Manajemen Perlengkapan Sekolah: Teori dan Aplikasinya. (Jakarta: Bumi Aksara, 2014), hlm.26.

${ }^{7}$ Djati Julitriarsa. Manajemen Umum. (Yogyakarta: BPFE Yogyakarta, 1998), hlm.3.
} 
sarana prasarana lebih terkendali. ${ }^{8}$

e. Pemeliharaan Sarana dan Prasarana Pendidikan

Pemeliharaan sarana dan prasarana merupakan kegiatan yang berupa menjaga keberlangsungan fungsi sarana dan prasarana pendidikan agar dapat digunakan secara berulang.

f. Inventarisasi Sarana dan Prasarana Pendidikan

Inventarisasi adalah pencatatan semua perlengkapan pendidikan yang dimiliki oleh sekolah secara sistematis, tertib, dan teratur berdasarkan ketentuan atau pedoman yang berlaku.

\section{g. Penghapusan Sarana dan Prasarana Pendidikan}

Penghapusan sarana dan prasarana adalah kegiatan untuk menghilangkan sarana dan prasarana dari daftar inventarisasi karena sudah tidak memiliki fungsi untuk kegiatan pembelajaran.

\section{Mutu Lulusan}

\section{a. Pengertian Mutu Lulusan}

Mutu dalam pendidikan dapat dilihat dari segi relevansinya dengan kebutuhan masyarakat, dapat tidaknya lulusan dapat melanjutkan ke jenjang selanjutnya bahkan sampai memperoleh suatu pekerjaan yang baik, serta kemampuan seseorang didalam mengatasi persoalan hidup. Mutu pendidikan dapat ditinjau dari kemanfaatan pendidikan bagi individu, masyarakat dan bangsa atau Negara. Secara spesifik ada yang melihat mutu pendidikan dari segi tinggi dan luasnya ilmu pengetahuan yang ingin dicapai oleh seseorang yang menempuh pendidikan.

Dikatakan pula bahwa dalam konteks pendidikan, pengertian mutu mengacu pada masukan, proses, keluaran, dan dampaknya. Adapun penjelasannya yaitu: (1) Mutu masukan dapat dilihat dari kondisi baik atau tidaknya masukan sumber daya manusia, seperti kepala sekolah, guru, laboran, staf, dan siswa. Memenuhi atau tidaknya criteria masukan material berupa alat peraga, buku-buku, kurikulum, sarana prasarana, dan lainlain. Memenuhi atau tidaknya perangkat lunak pendidikan, seperti peraturan, struktur oeganisasi dan deskripsi kerja. Mutu masukan yang berupa harapan, seperti visi, motivasi, ketekunan serta cita-cita. (2) Mutu proses meliputi kemampuan sumber daya sekolah mentransformasikan multijenis masukan dan situasi untuk

\footnotetext{
8 Agus Maimun \& Agus Zaenul Fitri. Madrasah Unggulan Lembaga Pendidikan: Alternatif di Era Konpetitif. (Malang: UIN Maliki Press, 2010), hlm.9.
} 
mencapai derajat nilai tambah tertentu bagi siswa. Seperti, kesehatan, kedisipilinan, kepuasan, keakraban, dan lain-lain. (3) Mutu keluaran, yakni hasil pendidikan dipandang bermutu jika mampu melahirkan keunggulan akademik (nilai) dan ekstrakurikuler (aneka jenis keterampilan) pada peserta didik yang dinyatakan lulus untuk satu jenjang pendidikan atau menyelesaikan program pembelajaran tertentu. ${ }^{9}$

Mutu pendidikan tidak hanya berada pada unsur masukan (input), tetapi juga proses, kinerja Sumber Daya Manusia yang mengelola, kreatifitas dan produktifitas meraka, terutama unsure keluaran atau lulusan (output) agar dapat memuaskan dan memenuhi harapan serta kebutuhan masyarakat sebagai pelanggan pendidikan. Dengan menggunakan konsep sistem maka input, proses, dan output yang ada dalam pendidikan memiliki hubungan yang saling mempengaruhi untuk dapat mencapai kepuasan dan memenuhi kebutuhan masyarakat.

Berdasarkan prinsip-prinsip tersebut dapat disimpulkan bahwa dalam usaha peningkatan mutu seluruh elemen yang ada dalam suatu organisasi ikut terlibat serta memiliki tugas, visi, misi yang sama. Prinsip peningkatan mutu lulusan sangat membutuhkan kepemimpinan yang profesional, komitmen pada perubahan, profesional pendidikan serta adanya administrator, guru, staf dan pengawas yang profesional.

\section{b. Peningkatan Mutu Lulusan}

Untuk meningkatkan mutu lulusan kita perlu melihat dari banyak sisi. Telah banyak pakar pendidikan mengemukakan pendapatnya tentang faktor penyebab dan solusi mengatasi kemerosotan mutu pendidikan di lndonesia. Dengan masukan ilmiah ahli itu, pemerintah tak berdiam diri sehingga tujuan pendidikan nasional tercapai.

Dalam persfektif makro banyak faktor yang mempengaruhi mutu lulusan, diantaranya faktor kurikulum, kebijakan pendidikan, fasilitas pendidikan, aplikasi teknologi informasi dan komunikasi dalam dunia pendidikan, khususnya dalam kegiatan proses belajar mengajar, aplikasi metode, strategi dan pendekatan pendidikan yang mutakhir dan modern, metode evaluasi pendidikan yang tepat, biaya pendidikan yang memadai, manajement pendidikan yang dilaksanakan secara profesional, sumberdaya manusia para pelaku pendidikan yang terlatih, berpengetahuan, berpengalaman dan profesional. $^{10}$

\footnotetext{
${ }^{9}$ Sudarwan Danim. Kinerja Staf dan Organisasi. (Bandung: Pustaka Setia, 2008), hlm.53.

${ }^{10}$ Abdul Hadis \& Nurhayati. Psikologi Pendidikan. (Jakarta: Rineka Cipta, 2010), hlm.3.
} 
Masukan ilmiah yang disampaikan para ahli dari negara-negara yang berhasil menerapkannya, seperti Amerika Serikat, Australia, Kanada, Selandia Baru dan Singapura selalu memunculkan konsep yang tidak selalu bisa diadopsi dan diadaptasi. Karena berbagai macam latar yang berbeda. Situasi, kondisi, latar budaya dan pola pikir bangsa kita tentunya tidak homogen dengan negara-negara yang diteladani. Malahan, konsep yang di impor itu terkesan dijadikan sebagai "proyek" yang bertendensi pada kepentingan pribadi atau kelompok tertentu, artinya, proyek bukan sebagai alat melainkan sebagai tujuan.

Dalam proses pendidikan guru memiliki peranan sangat penting dan strategis dalam membimbing peserta didik kearah kedewasaan, kematangan dan kemandirian, sehingga guru sering dikatakan ujung tombak pendidikan. Dalam melaksanakan tugasnya seorang guru tidak hanya menguasai bahan ajar dan memiliki kemampuan teknis edukatif tetapi memiliki juga kepribadian dan integritas pribadi yang dapat diandalkan sehingga menjadi sosok panutan bagi peserta didik, keluarga maupun masyarakat. ${ }^{11}$

Pada hakikatnya mutu lulusan dapat meningkat dengan adanya kontribusi dari berbagai pihak. Pemerintah sebagai pembuat kebijakan mempunyai andil dalam menanggung biaya minimum pendidikan. Sumber daya pendidikan perlu dioptimalkan dengan bekerjasama dengan sekolah- sekolah swasta. selain itu upaya-upaya pembangunan terus ditingkatkan dan memberikan perhatian khusus bagi anak serta meningkatkan pratisipasi masyarakat untuk mendukung penuh program pendidikan berangkat dari situ peneliti bermaksud mengadakan penelitian menejemen sarana prasarana dapat meningkan mutu lulusan di MTs Negeri Triwarno Kuthowinangun Kebumen.

\section{METODE PENELITIAN}

Jenis penelitian ini dapat diklasifikasikan sebagai penelitian lapangan (field research) yang bersifat deskriptif kualitatif. Waktu penelitian adalah antara bulan Mei sampai dengan Oktober 2017. Tempat penelitian adalah di MTs Negeri Triwarno Kutowinangun Kebumen Jawa Tengah.

Subjek penelitian ini yaitu Subjek penelitian ini adalah Kepala Madrasah dan Waka sarana prasarana di MTs Negeri Triwarno Kutowinangun Kebumen Jawa Tengah. Adapun

\footnotetext{
${ }^{11}$ Syaiful Sagala. Konsep dan Makna Pembelajaran. (Bandung: Alfabeta, 2007), hlm.99.
} 
informan dalam penelitian ini adalah orang tua, guru, dan siswa. Hal ini dipilih dengan pertimbangan para informan terlibat langsung dalam pelaksanaaan pendekatan saintifik.

Teknik pengumpulan data merupakan cara yang digunakan peneliti untuk memperoleh data penelitian yang dibutuhkan. Proses pengumpulan data dalam penelitian ini dilakukan dengan: observasi, wawancara mendalam, dan dokumentasi.

Keabsahan data dalam penelitian ini yaitu mengecek balik derajat kepercayaan suatu informasi yang diperoleh melalui waktu dan alat yang berbeda dengan jalan membandingkan data hasil pengamatan dengan hasil wawancara atau hasil dokumen lain. Dalam menguji keabsahan data peneliti menggunakan tehnik Triangulasi, yakni teknik pemeriksaan keabsahan data yang memanfaatkan sesuatu yang lain diluar data untuk keperluan pengecekan atau sebagai pembanding terhadap data itu.Itu artinya melakukan validasi, dengan cara mengecek dokumen program dan bukti tertulis lainnya. ${ }^{12}$ Dalam penelitian ini menggunakan Triangulasi metode yaitu menggunakan dua strategi yaitu: (1) Pengecekan terhadap derajat kepercayaan penemuan hasil penelitian dengan beberapa tehnik pengumpulan data; (2) Pengecekan derajat kepercayaan beberapa sumber data dengan metode yang sama.

Langkah-langkah yang dilakukan penulis lakukan untuk menganalisis data yang sudah diperoleh dari hasil observasi, wawancara, dan dokumentasi yaitu dengan menggunakan model analisis data Miles dan Huberman sebagaimana yang dikutip oleh Sugiyono, yaitu reduksi data (data reduction), penyajian data (data display), dan penarikan kesimpulan (conclusion drawing/verification). ${ }^{13}$

\section{HASIL PENELITIAN DAN PEMBAHASAN}

Berdasarkan hasil penelitian tentang Manajemen Sarana dan Prasarana dalam Peningkatan Mutu Lulusan di MTs Negeri Kutowinangun Kebumen diperoleh hasil sebagai berikut.

\section{Perencanaan Saran dan Prasaran (Planing) di MTs Negeri Kutowinangun Kebumen}

Perencanaan sarana dan prasarana di MTs Negeri Kutowinangun Kebumen merupakan langkah menetapkan kebutuhan sarana dan prasarana program yang akan dilaksanakan berdasarkan kondisi sarana dan prasarana yang dimiliki. Perencanaan sarana dan prasarana program melalui serangkaian tahapan yaitu rapat koordinasi,

\footnotetext{
${ }^{12}$ Michael Quinn Patton. Metode Evaluasi Kualitatif. (Yogyakarta: Pustaka Pelajar, 2006), hal. 280

${ }^{13}$ Sugiyono, Metode Penelitian Pendidikan, (Bandung: Alfabeta. 2009), hal. 254
} 
penetapan program madrasah, serta penetapan kebutuhan sarana dan prasarana pendidikan. Setelah dilakukan rapat koordinasi madrasah, langkah selanjutnya dalam perencanaan sarana dan prasarana adalah penetapan program madrasah. Penetapan program di MTs Negeri Kutowinangun Kebumen dilakukan pada saat rapat koordinasi diawal semester. Penetapan program madrasah merupakan kesepakatan seluruh peserta rapat untuk program yang akan dilaksanakan dalam rangka peningkatan mutu pendidikan di MTs Negeri Kutowinangun Kebumen.

Langkah terakhir dalam perencanaan sarana dan prasaran program adalah penetapan kebutuhan. Penetapan kebutuhan sarana dan prasarana program di MTs Negeri Kutowinangun Kebumen merupakan langkah menentukan kebutuhan sarana dan prasarana yang mendukung berjalannya program madrasah yang telah disepakati. Penetapan kebutuhan sarana dan prasarana program dilakukan pada saat rapat koordinasi diawal semester. Proses penetapan kebutuhan sarana dan prasarana program berdasarkan masukan dari guru, staf tata usaha, dan kesepakatan bersama pada rapat awal semester.

Berdasarkan temuan penelitian di MTs Negeri Kutowinangun Kebumen menunjukkan bahwa: (a) pembelian sarana dan prasarana dengan cara menyeleksi, (b) pendistribusian disalurkan tiap program jurusan dan kelas masing-masing. Setelah sarana dan prasarana yang diperlukan telah dimiliki oleh sekolah maka dalam hal penggunaan sarana dan prasarana harus dilakukan secara efektif dan efisien sesuai fungsinya, agar barang yang sudah dibeli dapat bermanfaat sesuai dengan kebutuhan. Penggunaan barang berkaitan dengan proses pemakaian dan peminjaman barang yang dilakukan oleh warga sekolah.

Perencanaan sarana dan prasarana dapat diartikan sebagai keseluruhan proses perkiraan secara matang rancangan pembelian, pengadaan, rehabilitasi, distribusi sewa atau pembuatan peralatan dan perlengkapan yang sesuai dengan kebutuhan. Perencanaan kebutuhan merupakan rincian fungsi perencanaan yang mempertimbangkan suatu faktor kebutuhan yang harus dipenuhi. Dalam menentukan kebutuhan diperlukan beberapa data diantaranya adalah distribusi dan komposisi, jenis, jumlah, dan kondisi (kualitas) sehingga berhasil guna, tepat guna, dan berdaya guna dan kebutuhan dikaji lebih lanjut untuk disesuaikan dengan besaran pembiayaan dari dana yang tersedia.

\section{Pengorganisasian Sarana dan Prasarana (Organizing) di MTs Negeri Kutowinangun Kebumen}

Pengorganisasian sarana dan prasarana merupakan suatu kegiatan mengelompokkan tanggung jawab terhadap masing-masing fungsi pengelola dalam 
bidang sarana dan prasarana pendidikan. Apabila dalam pengorganisasian berjalan sesuai dengan fungsi dan tugas yang diberikan maka organisasi dalam sarana dan prasarana akan berjalan dengan lancar dan baik. Pengorganisasian sarana dan prasarana meliputi pengaturan struktur organisasi pengelola sarana dan prasarana, pembagian tugas kerja/job deskripsi, pengaturan alat dan bahan praktek, serta pengaturan kegiatan praktek.

Peran penanggung jawab pengelola sarana dan prasarana adalah administrasi sarana dan prasarana, merencanakan sarana dan prasarana pendidikan, merencanakan dan mengelola kebutuhan alat dan bahan, mengusulkan kebutuhan alat dan bahan sebagai sarana dan prasarana pendidikan, melaporkan kondisi sarana dan prasarana kepada kepala madrasah. Peran kepala madrasah menjadi sangat penting dan besar yaitu membimbing dan memotivasi bawahannya. Dukungan dan perhatian positif yang diberikan kepala madrasah akan sangat membantu pengelola laboratorium dalam menjalankan tugas mereka sebaik mungkin serta mereka juga merasa dihargai dalam pekerjaannya.

Pengorganisasi merupakan suatu proses penyusunan struktur organisasi dan tersedianya sumberdaya (tenaga, keuangan, prasarana dan sarana) dalam organisasi. Terdapat dua aspek penting dalam kegiatan pengorganisasian yaitu pembagian kerja dan departemensasi. Pembagian tugas yang dimaksud adalah penyesuaian tugas pekerjaan agar setiap petugas dalam organisasi bertanggung jawab melaksanakan sekumpulan kegiatan yang terbatas. Hasil dari pekerjaan pengorganisasian adalah terbentuknya wadah (entity) atau satuan organisasi yang didalamnya ada perangkat organisasi agar tugas-tugas yang dipercayakan kepada pendukung dapat terlaksana.

Pengorganisasian adalah suatu proses yang menyangkut perumusan dan rincian pekerjaan dan tugas serta kegiatan yang berdasarkan struktur organisasi formal kepada orang-orang yang memiliki kesanggupan dan kemampuan melaksanakan nya sebagai prasyarat bagi terciptanya kerjasama yang harmonis dan optimal ke arah tercapainya tujuan secara efektif dan efisien. Pengorganisasian ini meliputi langkahlangkah antara lain: (a) Mengidentifikasi tujuan- tujuan dan sasaran yang telah di tetapkan sebelumnya. (b) Mengkaji kembali pekerjaan yang telah di rencanakan dan merincinya menjadi sejumlah tugasdan menjabarkan menjadi sejumlah kegiatan. (c) Menentukan personil yang memiliki kesanggupan dan kemampuan untuk melaksanakan tugas dan kegiatan tersebut. (d) Memberikan informasi yang jelas kepada petugas tentang tugas kegiatan yang harus di laksanakan, mengenai waktu dan 
tempatnya, serta hubungan kerja dengan pihak yangn terkait.

\section{Pengarahan/Penggerakkan Sarana dan Prasarana (Actuating) di MTs Negeri Kutowinangun Kebumen}

Penggerakan sarana dan prasarana rumah tangga di MTs Negeri Kutowinangun Kebumen dilakukan untuk memenuhi kebutuhan sarana dan prasarana pendidikan agar kegiatan belajar mengajar dapat berjalan dengan baik. Pengadaan sarana dan prasarana merupakan otonomi madrasah dengan anggaran tersendiri yang berasal dari anggaran sekolah dari pemerintah, dana BOS atau donatur. Proses pengadaan sarana dan prasarana ditetapkan oleh kepala madrasah dengan koordinasi bendahara kemudian guru (penanggung jawab sarana prasarana) menyediakan barang apa saja sesuai kebutuhan.

Pemeliharaan prasarana di MTs Kutowinangun Kebumen merupakan pemeliharaan prasarana yang ada agar dapat digunakan sewaktu-waktu dalam keadaan baik. Pemeliharaan prasarana pendidikan di MTs Negeri Kutowinangun Kebumen dilakukan dengan pengecekan berkala, perbaikan berdasarkan kondisi bangunan. Pengecekan berkala prasarana madrasah untuk pencegahan kerusakan berat atau kecelakaan yang tidak diinginkan. Selanjutnya, perbaikan berdasarkan kondisi bangunan dilakukan untuk peningkatan mutu dan kualitas bangunan yang dianggap kurang maksimal dalam mendukung kegiatan belajar mengajar.

Pemeliharaan sarana di MTs Negeri Kutowinangun Kebumen merupakan pemeliharaan sarana madrasah agar dapat digunakan dalam kegiatan belajar mengajar dengan kondisi yang baik. Pemeliharaan sarana madrasah menjadi tanggung jawab masing-masing penanggung jawab ruang kerja dan penanggung jawab kelas. Pemeliharaan sarana di MTs Negeri Kutowinangun Kebumen masih membutuhkan gudang penyimpanan agar sarana pendidikan yang tidak terpakai dapat terjaga dengan aman.

Pemeliharaan merupakan kegiatan penjagaan atau pencegahan dari kerusakan suatu barang, sehingga barang tersebut selalu dalam kondisi baik dan siap pakai. Pemeliharaan dilakukan secara continue terhadap semua barang-barang inventaris kadang-kadang dianggap sebagai suatu hal yang sepele, padahal pemeliharaan ini merupakan suatu tahap kerja yang tidak kalah pentingnya engan tahap-tahap yang lain dalam administrasi sarana dan prasarana. Sarana dan prasarana yang sudah dibeli dengan harga mahal apabila tidak dipelihara maka tidak dapat dipergunakan. Pemeliharaan dimulai dari pemakai barang, yaitu dengan berhati-hati dalam menggunakannya. 
Pemeliharaan yang bersifat khusus harus dilakukan oleh petugas professional yang mempunyai keahlian sesuai dengan jenis barang yang dimaksud.

Pengadaan adalah kegiatan yang dilakukan untuk menyediakan semua jenis sarana dan prasarana pendidikan persekolahan yang sesuai dengan kebutuhan dalam rangka mencapai tujuan yang telah ditetapkan. Dalam konteks persekolahan, pengadaan merupakan segala kegiatan yang dilakukan dengan cara menyediakan semua keperluan barang atau jasa berdasarkan hasil perencanaan dengan maksud untuk menunjang kegiatan pembelajaran agar berjalan secara efektif dan efisien sesuai dengan tujuan yang diinginkan.

Pengadaan sarana dan prasarana merupakan fungsi operasional pertama dalam manajemen sarana dan prasarana pendidikan persekolahan. Fungsi ini pada hakikatnya merupakan serangkaian kegiatan untuk menyediakan sarana dan prasarana pendidikan persekolahan sesuai dengan kebutuhan, baik berkaitan dengan jenis dan spesifikasi, jumlah, waktu maupun tempat, dengan harga dan sumber yang dapat dipertanggungjawabkan.

Pengadaan barang, baik yang dilakukan sendiri oleh sekolah maupun dari luar sekolah, hendaknya dapat dicatat sesuai dengan keadaan dan kondisinya. Hal itu dimaksudkan sebagai upaya pengecekan, serta melakukan pengontrolan terhadap keluar/masuknya barang atau sarana dan prasarana milik sekolah. Catatan tersebut dituangkan dalam format pengadaan sarana dan prasarana pendidikan yang disajikan dalam bentuk tabel sebagai rujukan bagi sekolah dalam melakukan aktivitas pengadaan sarana dan prasarana untuk sekolah.

Penghapusan sarana dan prasarana pendidikan di MTs Negeri Kutowinangun Kebumen dilakukan sesuai kondisi barang yang sudah tidak terpakai agar tidak memenuhi tempat. Proses penghapusan sarana dan prasarana di MTs Negeri Kutowinangun Kebumen melalui rangkaian tahapan yaitu pemilihan barang, penjualan barang. Penghapusan sarana dan prasarana dikelola oleh madrasah sendiri. Pemilihan barang yang akan dilakukan penghapusan di MTs Negeri Kutowinangun Kebumen yaitu pemilihan barang yang sudah rusak dan barang tidak terpakai untuk dilakukan penghapusan. Pemilihan barang dilakukan oleh penanggung jawab sarana prasarana dengan persetujuan kepala madrasah dan bendahara.

Berdasarkan temuan penelitian di MTs Negeri Kutowinangun Kebumen menunjukkan bahwa: (a) penggunaan pembelajaran disesuaikan kebutuhan guru dan siswa, (b) penggunaan ada tata tertib yang harus dipatuhi oleh siswa, (c) pemeliharaan 
barang diserahkan ke pihak-pihak yang bertanggung jawab tiap masing-masing program jurusan serta masing- masing kelas, (d) pemeliharaan gedung dilakukan satu tahun sekali, dilakukan pada awal tahun ajaran baru, (e) pemeliharaan buku dilakukan 6 bulan sekali.

\section{Pengontrolan Sarana dan Prasaranan (Controling) di MTs Negeri Kutowinangun}

\section{Kebumen}

Kontrol akan sarana dan prasarana di MTs Negeri Kuthowinangun Kebumen dilakukan dengan inventarisasi sarana dan prasarana pendidikan. Inventarisasi sarana dan prasarana pendidikan di MTs Negeri Kutowinangun Kebumen akan dilakukan berdasarkan Direktorat Jendral Peningkatan Mutu Pendidik dan Tenaga Kependidikan Departemen Pendidikan Nasional tahun 2007, mengenai Manajemen Sarana dan Prasarana Pendidikan Persekolahan Berbasis Sekolah.

Tahapan yang saat ini dilakukan yaitu pendataan sarana dan prasarana yang dimiliki. Petugas inventarisasi sarana dan prasarana yaitu guru (bagian sarana prasarana) dengan kondisi madrasah yang belum lama pindah bangunan serta masih dalam proses penataan ulang. MTs Negeri Kutowinangun Kebumen memiliki sarana dan prasarana yang unik secara fisik. Penataan ruang kelas dan material bangunan berbeda dengan sekolah-sekolah pada umumnya.

Inventarisasi merupakan langkah awal yang dilakukan dalam menerima barang, hal ini dilakukan dalam rangka usaha penyempurnaan pengelolaan barang-barang yang telah dimiliki agar tertap terjaga dengan baik. Tujuan dari inventarisasi adalah untuk menjaga dan menciptakan tertib administrasi sara dan prasarana yang dimiliki suatu sekolah, menghemat keuangan sekolah, baik dalam pengadaan maupun untuk pemliharaan dan penghapusan sarana dan prasarana sekolah, sebagai bahan atau pedoman untuk menghitung kekayaan suatu sekolah dalam bentuk materil yang dapat dinilai dengan uang dan untuk memudahkan pengawasan dan pengendalian sarana dan prasarana yang dimiliki oleh suatu sekolah.

Daftar inventarisasi barang yang disusun suatu organisasi yang lengkap, teratur dan berkelanjutan dapat memberikan manfaat menyediakan data dan informasi dalam rangka menentukan kebutuhan dan menyusun kebutuhan barang, memberikan data dan informasi untuk dijadikan bahan/pedoman dalam pengarahan pengadaan barang, memberikan data dan informasi untuk dijadikan bahan/pedoman dalam penyaluran barang, memberikan data dan informasi dalam menentukan keadaan barang (tua, rusak, lebih) sebagai dasar untuk menetapkan penghapusannya, dan memberikan data dan 
informasi dalam rangka memudahkan pengawasan dan pengendalian barang.

Administrasi sarana dan prasarana pendidikan merupakan hal yang sangat menunjang atas tercapainya suatu tujuan dari pendidikan, sebagai seorang personal pendidikan kita dituntut untuk menguasi dan memahami administrasi sarana dan prasarana, untuk meningkatkan daya kerja yang efektif dan efisien serta mampu menghargai etika kerja sesama personal pendidikan, sehingga akan tercipta keserasian, kenyamanan yang dapat menimbulkan kebanggaan dan rasa memiliki baik dari warga sekolah maupun warga masyarakat sekitarnya. Lingkungan pendidikan akan bersifat positif atau negatif itu tergantung pada pemeliharaan administrasi sarana dan prasarana itu sendiri.

Inventarisasi dilakukan dalam rangka usaha penyempurnaan pengurusan dan pengawasan yang efektif terhadap sarana dan prasarana yang dimiliki oleh suatu sekolah. Barang inventaris sekolah adalah semua barang milik Negara yang diadakan atau dibeli melalui dana dari pemerintah guna menunjang kelancaran proses pembelajaran. Berdasarkan temuan penelitian di MTs Negeri Kutowinangun Kebumen menunjukkan bahwa: (a) inventaris dilakukan oleh staf yang khusus menanganinya, (b) pelaksanaan inventaris yaitu pencatatan seluruh barang, pencatatan laporan kondisi pemakaian dan rekapitulasi selama setahun, (c) inventaris di program jurusan RPL dengan buku induk, buku non inventaris, buku laporan pemakaian, dan pencatatan rekapitulasi selama setahun, (d) pencatatan buku di perpustakaan dengan pencatatan daftar, pencatatan buku sesuai golongan, pencatatan laporan buku yang dihapus

Proses pendidikan memang memerlukan fasilitas atau peralatan, tetapi semua fasilitas atau peralatan harus diadakan sesuai dengan kebutuhan, Jika fasilitas itu sudah diadakan, harus dimanfaatkan melalui proses yang optimal. Dalam sistem pendidikan, proses sama pentingnya dengan masukan instrumental dan masukan lingkungan. Semuanya akan menjadi penentu dalam mencapai keluaran (out put) dan hasil pendidikan (out come). Di samping itu untuk menciptakan kwalitas atau mutu tersebut tentu juga harus di penuhinya banyak hal selain sarana prasarana akan tetapi tentu ada kompunen yang lain, bicara mutu pendidikan tidaklah sesederhana yang di ucapakan atau yang sering kita dengar, tentu kita perlu mengerti apa itu mutu dan bagaimana cara mewujudkannya.

Kegiatan penghapusan dilakukan dengan terlebih dahulu dengan mendata semua sarana prasarana, dengan mendata terlebih dahulu akan diketahui sarana prasarana yang masih bisa dipakai atau dimanfaatkan atau sudah tidak bisa digunakan 
sehingga harus dihapus keberadaannya. Penghapusan itu dilakukan dengan tujuan untuk memperbaiki sarana dan prasarana yang sudah tidak layak pakai. Berdasarkan temuan penelitian di MTs Negeri Kutowinangun Kebumen menunjukkan bahwa: (a) penghapusan dilakukan laporan awal dengan membuat berita acara, (b) penghapusan untuk barang yang tidak layak dipakai, (c) terdapat syarat penghapusan, (d) pendataan awal untuk penghapusan, (e) penghapusan dilakukan tim dan disetujui kepala sekolah.

\section{Mutu Lulusan di MTs Negeri Kutowinangun Kebumen.}

Pengertian mutu, Mutu mengandung makna derajat (tingkat) keunggulan suatu produk (hasil kerja/upaya) baik berupa barang maupun jasa; baik yang tangible maupun yang intangible. Dalam konteks pendidikan pengertian mutu, dalam hal ini mengacu pada proses pendidikan dan hasil pendidikan. Dalam "proses pendidikan" yang bermutu terlibat berbagai input, seperti; bahan ajar (kognitif, afektif, atau psikomotorik), metodologi (bervariasi sesuai kemampuan guru), sarana sekolah, dukungan administrasi dan sarana prasarana dan sumber daya lainnya serta penciptaan suasana yang kondusif. Manajemen sekolah, dukungan kelas berfungsi mensinkronkan berbagai input tersebut atau mensinergikan semua komponen dalam interaksi (proses) belajar mengajar baik antara guru, siswa dan sarana pendukung di kelas maupun di luar kelas; baik konteks kurikuler maupun ekstra-kurikuler, baik dalam lingkup subtansi yang akademis maupun yang non-akademis dalam suasana yang mendukung proses pembelajaran.

Dalam sistem pendidikan, konsentrasi terhadap kualitas bukan semata-mata tanggung jawab sekolah dan pemerintah, tetapi merupakan sinergi antara berbagai komponen termasuk masyarakat. Oleh karena itu, masyarakat harus sadar mutu, berkontribusi terhadap peningkatan mutu, dan senantiasa memilih mutu dalam sikap hidupnya. Pada format pengelolaan pendidikan yang sentralistik, sekolah menjadi unit birokrasi dan guru sering diposisikan sebagai bagian dari karyawan birokrasi pemerintahan. Sebaliknya, pada format pengelolaan pendidikan yang didesentralisasikan, sekolah dikonsepsikan sebagai unit akademik dan guru merupakan tenaga profesional.

Mutu dalam konteks "hasil pendidikan" mengacu pada prestasi yang dicapai oleh sekolah pada setiap kurun waktu tertentu (apakah tiap akhir cawu, akhir tahun, 2 tahun atau 5 tahun, bahkan 10 tahun). Prestasi yang dicapai atau hasil pendidikan (student achievement) dapat berupa hasil test kemampuan akademis (misalnya ulangan umum, UAN, UAS). Dapat pula prestasi di bidang lain seperti prestasi di suatu cabang olah 
raga, seni atau keterampilan tambahan tertentu misalnya : komputer, beragam jenis teknik, jasa. Bahkan prestasi sekolah dapat berupa kondisi yang tidak dapat dipegang (intangible) seperti suasana disiplin, keakraban, saling menghormati, kebersihan dan sebagainya.

Demikian juga dengan MTs Negeri Triwarno Kutowinangun Kebumen terbukti dengan perencanaan yang matang, pengorganisasian yang baik, menggerakkan pengadaan dan penginventarisasian dengan tepat, pengontrolan dengan baik dapat meningkatkan mutu lulusan di MTs Negeri Triwarno Kutowinangun Kebumen.

Usaha-usaha yang dilakukan dalam upaya peningkatan kualitas pembelajaran adalah merupakan suatu proses yang dilaksanakan secara dinamis dan berkesinambungan dalam rangka meningkatkan kualitas pendidikan dan berbagai faktor yang berkaitan dengannya, dalam upaya pencapaian tujuan pendidikan secara efektif dan efisien. Berdasarkan temuan penelitian di MTs Negeri Kutowinangun Kebumen menunjukkan bahwa: (a) Faktor yang mendukung keberhasilan manajemen sarana dan prasarana pendidikan yakni disekolah ini mempunyai tenaga-tenaga administrasi yang ahli dan bagus, (b) Usaha yang dilakukan ditekankan dalam segi pengadaan karena sarana yang dibutuhkan sangat banyak dan tidak bisa semuanya langsung diberikan oleh pemerintah dananya, (c) Mengadakan workshop pelatihan untuk guru, (d) Melengkapi sarana penunjang yang mungkin dapat meningkatkan minat siswa untuk sekedar datang ke perpustakaan meningkatkan minat membaca buku, (e) Memonitor kebutuhan mana yang harus didahulukan pengadaanya, (f) Penggunaan dan pemeliharaan ditingkatkan oleh warga sekolah yang juga ikut memiliki sarana dan prasarana yang ada.

Pendistribusian sarana dan prasarana dalam upaya peningkatan kualitas pembelajaran di MTs Negeri Kutowinangun Kebumen yang meliputi: (a) pembelian sarana dan prasarana dengan cara menyeleksi kemudian dipilih barang yang mempunyai standar sekolah yang telah ditentukan, (b) proses pendistribusian setelah pembelian dilakukan alokasi barang yaitu penyaluran barang kepada pihak-pihak yang membutuhkan. Setelah barang dibeli kemudian disalurkan kepada tiap program jurusan dan kelas masing-masing.

Penggunaan dan pemeliharaan sarana dan prasarana dalam upaya peningkatan kualitas pembelajaran di MTs Negeri Kutowinangun Kebumen yang meliputi: (a) penggunaan sarana dan prasarana dalam pembelajaran disesuaikan dengan kebutuhan guru dan siswa, (b) dalam menggunkaan sarana dan prasarana sekolah ada 
tata tertib yang harus dipatuhi oleh siswa. Tata tertib tersebut berada di setiap ruang lab dan bengkel. Tata tertib juga terdapat pada ruang perpustakaan, (c) dalam proses pemeliharaan barang di MTs Negeri Kutowinangun Kebumen diserahkan kepada pihak-pihak yang bertanggung jawab pada masing-masing program jurusan serta masing-masing kelas. Proses ini menyangkut pendistribusian, penggunaan dan pemeliharaan sarana dan prasarana, (d) untuk pemeliharaan gedung juga dilakukan satu tahun sekali, seperti pengecatan yaitu dilakukan pada awal tahun ajaran baru (e) pemeliharaan buku juga dilakukan 6 bulan sekali, pemeliharaan tersebut dilakukan seperti menyampul buku. Kegiatan menyampul buku ini dilakukan oleh petugas perpustakaan yang juga penanggungjawab ruang perpustakaan.

Inventaris sarana dan prasarana dalam upaya peningkatan kualitas pembelajaran yang meliputi: (a) dalam inventaris sarana dan prasarana di MTs Negeri Kutowinangun Kebumen ada staf sendiri yang memang diberi tugas untuk melakukan pencatatan barang-barang yang yang telah diadakan, (b) pelaksanaan inventaris sarana dan prasarana terdapat proses yaitu dari pencatatan seluruh barang yang telah diadakan sampai ke pencatatan laporan kondisi saat pemakaian dan rekapitulasi selama setahun, (c) sistem inventaris barang di program jurusan RPL dalam buku induk, buku non inventaris yaitu untuk barang-barang yang habis pakai, buku laporan pemakaian, dan pencatatan rekapitulasi barang-barang yang masuk dan keluar selama setahun, (d) pencatatan buku di perpustakaan dilakukan oleh pihak sarana dan prasarana. Inventaris dimulai dengan pencatatan daftar buku yang akan diadakan kemudian, pencatatan buku sesuai golongan, pencatatan lapran buku-buku yang dihapus.

Penghapusan sarana dan prasarana dalam upaya peningkatan kualitas pembelajaran yang meliputi: (a) dalam melakukan penghapusan harus terlebih dahulu membuat laporan atau berita acara kepada kepala sekolah bahwa aka nada sarana yang mau dihapus, jika laporan atau berita acara tersebut disetujui oleh kepala sekolah dengan catatan sarana dan prasarana tersebut memang dalam keadaan rusak dan sudah tidak bisa digunakan lagi maka tim segera melakukan penghapusan sarana dan prasarana tersebut, (b) kegiatan penghapusan dilakukan karena sarana prasarana tersebut sudah tidak layak pakai, sudah rusak, sudah tidak sesuai dengan kurikulum yang berlaku, sehingga harus dihapus, (c) terdapat sayarat- sayarat khusus dalam penghapusan sarana prasarana diantaranya adalah barang tersebut sudah tidak layak dalam segi kemanfaatannya, sudah rusak sehingga perlu perbaikan atau pergantian dengan yang baru, (d) dalam kegiatan penghapusan harus terlebih dahulu dilakukan 
pendataan terhadap saran prasarana yang akan dihapus, apakah barang tersebut layak untuk dihapus atau diperbaiki, jika memang sudah memenuhi syarat untuk dihapus maka sarana prasarana tersebut akan dihapus, (e) penghapusan sarana prasarana ini dilakukan oleh tim sarana prasarana sekolah yang harus disetujui oleh kepala sekolah.

Usaha-usaha yang dilakukan dalam upaya peningkatan kualitas pembelajaran yang meliputi: (a) Faktor yang mendukung keberhasilan manajemen sarana dan prasarana pendidikan yakni disekolah ini mempunyai tenaga-tenaga administrasi yang ahli dan bagus, selain itu adanya dukungan yang tinggi dari semua warga sekolah termasuk pemerintah daerah dalam proses pelaksanaan program yang direncanakn oleh sekolah bagi peningkatan mutu sekolah, (b) Usaha yang dilakukan ditekankan dalam segi pengadaan karena sarana yang dibutuhkan sangat banyak dan tidak bisa semuanya langsung diberikan oleh pemerintah dananya. Oleh karena itu pengalokasian dana sebisa mungkin diperuntukan terhadap sarana yang dibutuhkan, (c) Mengadakan workshop pelatihan untuk guru. Dimaksudkan untuk meningkatkan performa guru dalam menyampaikan materi dan metode pembelajaran dikelas, (d) Melengkapi sarana penunjang yang mungkin dapat meningkatkan minat siswa untuk sekedar datang ke perpustakaan. Yakni perpustakaan plus hotspot internet, media audio-visual dan media game edukasi, (e) Usaha yang dilakukan dalam meningkatkan kualitas pembelajaran melalui manajemen sarana dan prasarana lebih ke memonitor kebutuhan mana yang harus didahulukan pengadaanya, (f) Usaha yang dilakukan dalam upaya peningkatan kualitas pembelajaran melalui manajemen sarana dan prasarana lebih dalam hal penggunaan dan pemeliharaan. Sebagai warga sekolah yang juga ikut memiliki sarana dan prasarana yang ada.

\section{KESIMPULAN DAN SARAN}

\section{Kesimpulan}

Berdasarkan hasil penelitian tentang Menejemen Sarana dan Prasarana dalam Meningkatkan Mutu Lulusan di MTs Negeri Triwarno Kutowinangun Kebumen dapat ditarik kesimpulan bahwa:

a. Perencanaan Saran dan Prasaran (Planing)

Perencanaan sarana dan prasarana program melalui serangkaian tahapan yaitu rapat koordinasi madrasah, penetapan program madrasah, serta penetapan kebutuhan sarana dan prasarana pendidikan. 


\section{b. Pengorganisasian Saranadan Prasarana (Organizing)}

Pengorganisasian sarana dan prasarana meliputi pengaturan struktur organisasi pengelola sarana dan prasarana, pembagian tugas kerja/job deskripsi, pengaturan alat dan bahan praktek, serta pengaturan kegiatan praktek.

c. Pengarahan/Penggerakkan Sarana dan Prasarana (Actuating)

1) Pengarahan sarana dan prasarana merupakan otonomi madrasah dengan anggaran tersendiri yang berasal dari anggaran madrasah dari pemerintah berupa dana BOS dan dana wali murid yang dikelola oleh komite.

2) Pemeliharaan prasarana pendidikan di MTs Negeri Triwarno Kutowinangun Kebumen dilakukan dengan pengecekan berkala, perbaikan berdasarkan kondisi bangunan. Pemeliharaan sarana di MTs Negeri Triwarno Kutowinangun Kebumen merupakan pemeliharaan sarana madrasah agar dapat digunakan dalam kegiatan belajar mengajar dengan kondisi yang baik.

\section{d. Pengontrolan Sarana dan Prasaranan (Controling)}

Kontrol akan sarana dan prasarana di MTs Negeri Triwarno Kutowinangun Kebumen dilakukan dengan inventarisasi sarana dan prasarana pendidikan. Inventarisasi sarana dan prasarana pendidikan di MTs Negeri Triwarno Kutowinangun Kebumen akan dilakukan berdasarkan Direktorat Jendral Peningkatan Mutu Pendidik dan Tenaga Kependidikan Departemen Pendidikan Nasional Tahun 2007, mengenai Manajemen Sarana dan Prasarana Pendidikan Persekolahan Berbasis Sekolah.

\section{Saran-saran}

Berdasarkan temuan penelitian mengenai pengelolaan sarana dan prasarana pendidikan di MTs Negeri Triwarno Kutowinangun Kebumen, maka peneliti mengemukakan saran sebagai berikut:

a. Bagi Madrasah:

1) Madrasah perlu tim pengadaan sarana dan prasarana secara khusus dan bendahara tidak berhubungan langsung dalam pelaksanaan pengadaan sarana dan prasarana pendidikan.

2) Pengadaan sarana dan prasarana yang berhubungan dengan kebutuhan akan sarana dan prasarana hendaknya di rencanakan dengan baik bersama semua warga madrasah agar semua aspirasi warga dapat tertampung. 
b. Bagi Guru dan Siswa:

1) Penggunaan sarana dan prasarana hendaknya disesuaikan dengan kebutuhan agar diperoleh manfaat dari penggunaan tersebut. Seluruh warga madrasah hendaknya memanfaatkan sarana dan prasarana yang dimiliki madrasah agar tidak terbuang percuma hanya menjadi hiasan saja karena pada dasarnya semua fasilitas madrasah diadakan untuk memberikan layanan yang terbaik kepada semua warga madrasah.

2) Pemeliharaan sarana dan prasarana madrasah tidak hanya diserahkan pada petugas yang menanganinya saja, tetapi sumbangsih atau proaktif semua warga madrasah juga diperlukan agar semua program yang direncanakan dalam pemeliharaan madrasah dapat terealisasikan dengan baik demi kelangsungan proses pendidikan di madrasah.

c. Bagi Orangtua dan Stakeholder:

Peran serta masyarakat atau orang tua siswa tidak hanya berupa dukungan dana atau sumbangan fisik saja, tetapi bisa lebih dari itu. Peran serta masyarakat sudah dapat dianggap baik jika dapat terlibat dalam bidang pengelolaan madrasah, apalagi bila dapat masuk ke bidang akademik. Sehingga semua kebijakan dan keputusan yang diambil adalah kebijakan dan keputusan bersama dalam rangka mencapai tujuan pendidikan bersama.

d. Bagi Pengelola:

1) Pengelola, khususnya kepala bidang sarana dan prasarana bertanggung jawab atas kualitas pendidikan maupun hidup matinya proses pendidikan paling tidak melakukan pengembangan di bidang manajemen dan keuangan. Sehingga madrasah tetap eksis melaksanakan pendidikan dengan tidak mempersoalkan permasalahan manajemen dan kekurangan dana pembiayaan.

2) Kegiatan inventarisasi sarana dan prasarana pendidikan perlu bantuan guru lain serta staf tata usaha agar dapat terlaksana secara efektif dan efisien.

\section{DAFTAR PUSTAKA}

Abdul Hadis \& Nurhayati. (2010). Psikologi Pendidikan. Jakarta: Rineka Cipta.

Agus Maimun \& Agus Zaenul Fitri. (2010). Madrasah Unggulan Lembaga Pendidikan: Alternatif di Era Konpetitif. Malang: UIN Maliki Press.

Arifin \& Barnawi. (2012). Etika dan Profesi Kependidikan. Jogjakarta: Ar-Ruzz Media. 
Djati Julitriarsa. (1998). Manajemen Umum. Yogyakarta: BPFE Yogyakarta.

Husaini Usman. (2013). Manajemen: Teori, Praktik, dan Riset Pendidikan. Jakarta: Bumi Aksara.

Ibrahim Bafadal. (2014). Manajemen Perlengkapan Sekolah: Teori dan Aplikasinya. Jakarta: Bumi Aksara.

Mendiknas. (2007). Permendiknas RI Nomor 13 Tahun 2007 tentang Manajemen Sarana dan Prasarana Pendidikan Persekolahan.

Michael Quinn Patton. (2006). Metode Evaluasi Kualitatif. Yogyakarta: Pustaka Pelajar.

Republik Indonesia. (2003). Undang-undang Nomor 20 Tahun 2003 tentang Sistem Pendidikan Nasional.

Sudarwan Danim. (2008). Kinerja Staf dan Organisasi. Bandung: Pustaka Setia.

Sugiyono. (2009). Metode Penelitian Pendidikan. Bandung: Alfabeta.

Syaiful Sagala. (2007). Konsep dan Makna Pembelajaran. Bandung: Alfabeta. 